\title{
A human resources project implementation An actor-network theory perspective
}

\author{
Gibrán Rivera González \\ Information School, \\ University of Sheffield \\ gibran.rivera@sheffield.ac.uk
}

Andrew M. Cox Information School, University of Sheffield a.m.cox@sheffield.ac.uk

\section{Ricardo Flores}

\section{Zambada}

Instituto Tecnológico y de Estudios Superiores de Monterrey (EGADE) riflores@itesm.mx

\section{Abstract}

Two main objectives are aimed at this paper. Firstly, to suggest the use of Actor-Network Theory (ANT) as a suitable theory to inform the Implementation of a Human Resources Project (called ModeCo, Modelo de Competencias); and secondly, to shed some initial insights to understand some of the issues that shape the rhythm of this implementation. The paper draws on a qualitative study informed by ANT (Callon, 1986; Latour, 1987; Law, 1992) which is used as a 'sensitizing device' to describe how a Project Implementation (PI) takes place in a multi-campus University System in Mexico. We provide a number of statements that capture how ANT was useful in our study and suggest some issues that shaped the PI. We adopt an interpretive approach (Walsham, 1995; Walsham, 2006) and rely on data collected using a battery of different methods, including insights from 12 semi-structured interviews, project documents and attendance to online meetings. In terms of analysis our research rests on the principles of interpretive studies by Klein and Myers (1999).

Keywords: actor-network theory, project implementation, human resources, interpretive studies. 


\section{Implementación de un proyecto de recursos humanos. Una perspectiva basa- da en la teoría del actor-red}

\section{Resumen}

Este artículo tiene dos objetivos principales. Primero, sugerir el uso de la Teoría del Actor-Red (ANT por sus siglas en inglés) como una teoría que puede ser utilizada para analizar la implementación de un proyecto de recursos humanos (llamado ModeCo, Modelo de Competencias); y, segundo, proveer un entendimiento inicial sobre algunos de los principales eventos y situaciones que dieron forma al ritmo de la implementación de este proyecto. Este artículo se basa en una investigación cualitativa, la cual toma una perspectiva informada por la Teoría del Actor-Red (Callon, 1986; Latour, 1987; Law, 1992) que es utilizada como mecanismo de entendimiento para describir cómo un proyecto es implementado en una Universidad con múltiples campus en México. En este trabajo se ofrecen, primero, una serie de enunciados que capturan la manera en cómo la Teoría del Actor-Red fue útil para entender el proceso de implementación; y, segundo, se exponen los principales eventos y situaciones que afectaron dicho proceso de implementación. En esta investigación adoptamos un modelo interpretativo (Walsham, 1995; Walsham, 2006), mismo que se vale del uso de una batería de métodos, principalmente el uso de doce entrevistas semiestructuradas con diferentes actores del proyecto, documentos del proyecto y asistencia virtual a reuniones del Comité Directivo de recursos humanos. En términos de análisis nuestra investigación está basada en los principios propuestos por Klein and Myers (1999) para estudios interpretativos.

Palabras clave: teoría del actor-red, implementación de proyectos, recursos humanos, estudios interpretativos.

\section{Introduction}

Organizations are continuously involved in developing and implementing new projects (Schultz et al., 1987). The management of both IT-mediated projects and non IT-projects involves changes in the way in which work is performed and often represents a nightmare for the actors involved (Linde et al., 2003) resulting in intra-organizational tensions (Kuruppuarachchi et al., 2002) and leading to a set of social, political and technological issues that implementers have to deal with. To some extent, these tensions emerge because while organizations need to face change to meet new organizational demands, at the same time they typically 
have to maintain operational continuity (Huy, 2002). Several studies in the field of Project Management have been conducted to examine how a variety of Critical Success Factors (CSFs) shape a Project Implementation Process (e.g. Pinto and Slevin, 1986; Schultz et al., 1987; Martinez, 1994; Finney and Corbett, 2007). In this regard, factors such as clearly defined goals, sufficient resources allocation, top management support and commitment, visioning and planning, effective project managers, competent project team members, adequate communication, feedback capabilities, and user involvement, have been identified as CSFs when implementing new projects. Despite this huge literature, especially in the Project Management field, the reality is that there are still a big number of organizational projects that fail to achieve their expected goals. For example, Dinsmore et al. point out that many projects do not achieve even half of the benefits they were supposed to provide (Dinsmore et al., 2005) and Zhang et al., (2003) note that the implementation success rate for Enterprise Resource Planning projects (ERPs) is only about $33 \%$.

Based on the need of improving our understanding on how projects are implemented and bearing in mind how ANT can be helpful to accomplish this, in this paper we have two main objectives. First, to suggest the use of ANT as an alternative perspective to inform the Implementation of a Human Resources Project, in which the attention is shifted away from looking at the underlying CSFs to the idea of how a series of events and interactions of different human and non-human actors shape a Project Implementation. And second, to shed some initial insights to understand the main issues that shape the rhythm of this implementation. These socio-technical events/interactions occur along the implementation and might result in the creation, maintenance or sometimes competition of different actor-networks that strengthen or undermine the implementation. Particularly, the existence of competing actor-networks is of relevance for this study in that as we will show later on, the Human Resources Directors (HRDs) involved in the Project Implementation (PI) participate simultaneously in two different actor-networks, one supporting the implementation of a new project -and therefore promoting organizational change- and another one aiming to maintain the operational continuity of the organization.

The paper is presented as follows. First, we introduce some key concepts of ANT to be used in our interpretation followed by the research methods used to collect and analyze data. Next, we introduce a brief description of how the PI occurred, and then present the implementation process informed by ANT. Finally, we intro- 
duce a number of statements that capture how ANT was useful in our study and suggest a series of issues that finally shaped the project implementation.

\section{Key concepts and justification of ant}

Actor Network Theory (ANT) was first developed by Michael Callon (1986) and Bruno Latour (1987) as part of the field of Science and Technology Studies. At the very beginning ANT was concerned with how scientists achieve support of others regarding their propositions about scientific facts and how power and resources are acquired to perform their work (Van House, 2003). Since then, ANT has been concerned with how the work of society is accomplished (Callon, 1986; Latour, 1987).

In this research, we justify the use of ANT as our theoretical lens to explain a project implementation in that it has been particularly used as a theory to better understand how change processes and projects are implemented (Linde et al., 2003), how goals of projects are achieved through processes of translation (Monteiro, 2004), how IT-mediated change projects are implemented (Linde et al., 2003) and how the implementation of IS and situations involving innovation occur (Tatnall and Gilding, 1999).

The basic idea of ANT is to understand how humans and non-humans actors are brought together in stable, heterogeneous networks of aligned interests (Law, 1992). By tracing the transformation of these heterogeneous networks, ANT explores how networks of relations are composed and maintained over time and how sometimes they compete with other networks of aligned interests (Tatnall and Gilding, 1999). A core assumption in ANT is that neither social nor technical positions are privileged based upon the argument that the social is not simply human but a 'pattern networks of heterogeneous materials' (Law, 1992:381). Law argues that 'almost all of our interactions with other people are mediated through objects of one kind or another' (1992:381). These interactions, mediated through objects and networks of objects and people (Cho et al., 2008), create other networks. If the material in these networks would disappear the so-called social orders would disappear too (Law, 1992). Therefore, no distinction between human and nonhuman actors is made. Examples of actors in ANT include humans, groups of humans, ideologies, methodologies, concepts, computers, texts and other artifacts. Independently of the actor, and actor is also, always, a network produced from or as an effect of heterogeneous relations between people and objects (Law, 1992). In viewing non-humans as actors, a key issue is to know that the interests of a non- 
human actor can be equated to the interests that have been inscribed in it (Sarker and Sidorova, 2006). For instance, it can be suggested that the Human Resources Project Implementation (from now on only PI) has the interest to establish a new way to develop employees' competencies of the organization.

In ANT, actor-networks are continuously evolving. The process of transformation of networks is achieved through processes of translation (Callon, 1986) in which a temporary social order is created through changes of the alignment of interest in a network (Sarker and Sidorova, 2006). During the process of translation one actor or group of actors drives the process to enrol and mobilize others into a new network previously defined (Blackburn, 2002). The concept of translation as defined in ANT suggests that power should be treated as an accomplishment, not as an attribute (Van House, 2003), it is other people who are involved in the situation that confer power to an actor (Latour, 1986). Due to the power that potential users have to appropriate, ignore, change or betray an idea the final end of this idea largely depends on them (Latour, 1986). Therefore, once an idea has been created (e.g. the development of a HR model to develop employees' competencies) a core network needs to be established (Linde et al., 2003), a network with enough power to persuade others to perform the appropriate actions to achieve a successful translation. These processes of translation should be deployed over time and consist of four interrelated stages: Problematization, interessment, enrolment and mobilization (Callon, 1986:203).

In the problematization stage one or more key actors attempt to frame the nature of the problem in its own terms (Sarker and Sidorova, 2006) and identify and involve a number of actors whose roles and relationships configure an initial problemsolving network (Linde et al., 2003). At this stage it is crucial to redefine the problem and to establish an Obligatory Passage Point (OPP) that allows the actors to recognise that they will receive benefits from their involvement into the new network by sharing a focus of achieving certain goals. By establishing the OPP, the actors render themselves as indispensable (Callon, 1986). At this stage other actors need to be persuaded to pass through the OPP by modifying their alignments and behaviours to those of the emerging network. The second moment of translation is interessement. It refers to how allies are locked in place (Tatnall and Burgess, 2002). During this stage other heterogeneous actors are persuaded to agree that the interests defined by the focal actor are consistent with what their interests should be. Incentives for actors are created to pass through the OPP defined by the focal actor (Sarker and Sidorova, 2006). Through this process the emerging net- 
work creates incitement to lock actors into fixed places and weaken the influence of other actors that may disestablished the developing network (Linde et al., 2003). In the interessement process negotiations among actors may take place; however sometimes spokespersons or representatives negotiate on their behalf.

Frequently actors who are represented by their speakers fail to act as their representatives promised. This action is called betrayal (Callon, 1986). The third stage is called enrolment, in which roles in the network are defined and coordinated leading to the establishment of a stable network of alliances (Tatnall and Burgess, 2002). Since enrolment is necessarily temporary, betrayal by an actor is always possible (Sarker and Sidorova, 2006). In this stage, once the OPP has been defined, it has to be translated into a series of more specific sub-goals (Linde et al., 2003). If an agreement between actors is reached at this stage, such agreements need to be embodied into a medium or material (Cho et al., 2008) through inscriptions. Such inscriptions define a program of actions for actors and can be useful 'to create new inscriptions and understandings out of existing ones and coordinate work across space and time' (Latour, 1987:227). Often, inscriptions have properties of irreversibility that refer to the degree which it is impossible in a certain situation to going back to a point where alternative possibilities exist. Finally the stage of mobilisation occurs when 'the proposed solution gains wider acceptance and an even larger network of absent entities is created' (Tatnall and Burgess, 2002:185).

In ANT, in an effort to simplify their investigation, researchers tend to treat networks as individual actors (Sarker and Sidorova, 2006). Such a simplification is called punctualization. A black box represents a punctualization of an actor-network that is no longer questioned or tested (Callon and Latour, 1981) and thus the effects or behaviours of an actor-network can be taken for granted. In other works: 'black-boxing is the process by which sub-networks disappear' (Van House, 2003:14). A brief summary of the key concepts in ANT is provided in Table 1 (Adapted from Walsham, 1997; Sarker and Sidorova, 2006). 


\section{Table 1}

\section{Key concepts in actor-network theory}

\begin{tabular}{l|l}
\multicolumn{1}{c|}{ Concept } & \multicolumn{1}{c}{ Definition } \\
\hline Actor & Both human beings and nonhuman actors such as technological artefacts. \\
\hline Actor-network & $\begin{array}{l}\text { Related actors in a heterogeneous network of aligned interests, including } \\
\text { people, organizations and concepts. }\end{array}$ \\
\hline Translation & $\begin{array}{l}\text { The process of alignment of interests of a diverse set of actors with the } \\
\text { interests of the focal actor with the aim to mobilize support. }\end{array}$ \\
\hline Inscription & $\begin{array}{l}\text { A process of creation of artefacts that would ensure the protection of certain } \\
\text { interests. }\end{array}$ \\
\hline Problematization & $\begin{array}{l}\text { The first moment of translation, during which a focal actor defines identities } \\
\text { and interests of other actors that are consistent with its own interests and } \\
\text { establishes itself as an Obligatory Passage Point, thus rendering itself } \\
\text { indispensable. }\end{array}$ \\
\hline Interessement & $\begin{array}{l}\text { The second moment of translation, which involves negotiating with actors } \\
\text { to accept the definition of the focal actor. }\end{array}$ \\
\hline Enrolment & $\begin{array}{l}\text { The third moment of translation, wherein other actors in the network accept } \\
\text { or get aligned to the interests defined for them by the focal actor. }\end{array}$ \\
\hline Mobilization & When one solution gains wider acceptance and a larger network is created. \\
\hline Obligatory & $\begin{array}{l}\text { A situation that has to occur for all the actors to be able to achieve their } \\
\text { interests, as defined by the focal actor. }\end{array}$ \\
\hline Passage Point & $\begin{array}{l}\text { The degree to which it is impossible to go back to a point where alternative } \\
\text { possibilities exist. }\end{array}$ \\
\hline
\end{tabular}

Bearing in mind the ideas summarised in Table 1, we believe ANT offers a useful frame to explore how different actors are enrolled and persuaded to participate in a Human Resources Project Implementation and allows us to capture the dynamics and tensions that exist along the creation, maintenance, and evolution of actor-networks with aligned interests.

\section{Research approach}

We adopted an interpretive approach (Walsham, 1995; Walsham, 2006) and relied on data collected using a battery of different methods; mainly semi-structured 
interviews. Audiovisual materials in the form of recorded seminars; documents; and virtual observation were also used. The decision to use different methods was made on the light to benefit from the access to different actors involved and thus giving us the opportunity to gain a deeper understanding about the project. The use of different methods to collect data is justified in that these data allow us to achieve our goals. As Robey states:

[...] theoretical foundations for research and specific research methods are justified by research aims, or purposes. They should not be chosen because they conform to a dominant paradigm or because the researcher believes in their intrinsic value. Rather, theories and methods are justified on pragmatic grounds as appropriate tools for accomplishing research aims (Robey, 1996).

Research access was negotiated through an 'informal sponsorship' (Hammersley and Atkinson, 1995), which is the Human Resources President (HRP) of the organisation under study. The HRP gave full access to the research field and helped with the arrangements of the interviews.

The main sources of data were 12 face-to-face semi-structured interviews conducted during July and August 2009. Consistent with the sixth principle of interpretative research (Klein and Myers, 1999), an strategic selection of participants (Hammersley and Atkinson, 1995) was used to involve representatives of the relevant roles in the project at different levels of the organisation. The interviews were conducted, recorded and transcribed typically lasting between 50 and 90 minutes long. An attempt to interview people that provide examples of polar types (Eisenhardt, 1989) was made in order to get access to different interpretations of the actors involved.

Obtaining a diverse range of perspectives allowed us to gain a greater appreciation of the complexity of the phenomenon under study. During the face-to-face interviews we attempted to capture both the facts and the emotional reactions of the interviewees to different aspects of the project. The different data sources in the study are summarized in Table 2 . 
Table 2

Methods for data collection

\begin{tabular}{|c|c|c|c|}
\hline $\begin{array}{l}\text { Method/ } \\
\text { Source }\end{array}$ & Description & Timing & $\begin{array}{l}\text { Research participants } \\
\text { involved }\end{array}$ \\
\hline $\begin{array}{l}\text { Audiovisual } \\
\text { materials }\end{array}$ & $\begin{array}{l}\text { Online community seminar } \\
\text { (recorded). The online space to } \\
\text { support knowledge sharing during } \\
\text { the Project Implementation was } \\
\text { introduced to all HR staff. }\end{array}$ & $\begin{array}{l}120 \text { minutes - } \\
\text { April } 2009\end{array}$ & $\begin{array}{l}\text { HR Steering Committee } \\
\text { members, IT specialist } \\
\text { and HR Directors }\end{array}$ \\
\hline $\begin{array}{l}\text { Audiovisual } \\
\text { materials }\end{array}$ & $\begin{array}{l}\text { Audiovisual materials. } 11 \text { project- } \\
\text { related seminars (recorded). The } \\
\text { Competency-based Model was } \\
\text { introduced to all HR staff who } \\
\text { would be involved in the Project } \\
\text { Implementation }\end{array}$ & $\begin{array}{l}60 \text { minutes each } \\
\text { - May-June } \\
2009\end{array}$ & $\begin{array}{l}\text { HR Steering Committee } \\
\text { members and HR } \\
\text { Directors }\end{array}$ \\
\hline Interview & $\begin{array}{l}\text { Semi-structured interview to } \\
\text { the HRP. Audiotaped and fully } \\
\text { transcribed }\end{array}$ & $\begin{array}{l}55 \text { minutes - } \\
\text { July } 2009\end{array}$ & $\begin{array}{l}\text { Human Resources } \\
\text { President }\end{array}$ \\
\hline Interview & $\begin{array}{l}\text { Semi-structured interview to the } \\
\text { HRVP. Audiotaped and fully } \\
\text { transcribed }\end{array}$ & $\begin{array}{l}50 \text { minutes - } \\
\text { July } 2009\end{array}$ & $\begin{array}{l}\text { Human Resources Vice- } \\
\text { President }\end{array}$ \\
\hline Interview & $\begin{array}{l}\text { Semi-structured interview to } \\
\text { one Human Resources Vice- } \\
\text { Chancellor (HRVC). Audiotaped } \\
\text { and fully transcribed }\end{array}$ & $\begin{array}{l}50 \text { minutes - } \\
\text { August } 2009\end{array}$ & $\begin{array}{l}\text { Human Resources Vice- } \\
\text { Chancellor }\end{array}$ \\
\hline Interview & $\begin{array}{l}9 \text { semi-structured interviews to } \\
\text { HRDs. Audiotaped and fully } \\
\text { transcribed }\end{array}$ & $\begin{array}{l}50 \text { minutes on } \\
\text { average - July- } \\
\text { August } 2009\end{array}$ & $\begin{array}{l}\text { Human Resources } \\
\text { Directors }\end{array}$ \\
\hline $\begin{array}{l}\text { Observation } \\
\text { and analysis of } \\
\text { documents }\end{array}$ & $\begin{array}{l}\text { Observation and analysis of } \\
\text { documents during the first year } \\
\text { of the research. Observe how } \\
\text { participants use the online space. } \\
\text { Access to relevant documentation } \\
\text { of the project }\end{array}$ & $\begin{array}{l}\text { April 2009- } \\
\text { April } 2010\end{array}$ & $\begin{array}{l}\text { Users of the online } \\
\text { space/documents }\end{array}$ \\
\hline Observation & $\begin{array}{l}\text { Observation and notes taking. } \\
\text { Attendance to } 2 \text { Human } \\
\text { Resources Steering Committee } \\
\text { Meetings }\end{array}$ & $\begin{array}{l}180 \text { minutes } \\
\text { each - } \\
\text { November } 2009 \\
\text { and March } 2010\end{array}$ & $\begin{array}{l}\text { Members of the Steering } \\
\text { Committee }\end{array}$ \\
\hline
\end{tabular}

In terms of analysis our research rests on the principles of interpretive studies by Klein and Myers (1999). The process of analysis is based on the first principle of hermeneutic circle of interpretive studies (Klein and Myers, 1999) in which we carefully read and reflected on our data sources by iterating between the interdependent meaning of parts and the whole that they formed. What we also mean here is that when we read the texts, an awareness was emphasized by constantly questio- 
ning the surface meaning of what was said -in alignment with the seventh principle of inductive research (Klein and Myers, 1999)- in that meanings of what is said can go beyond the original intentions of the interviewees. If indeed, during the data collection process a strategic selection of participants (Hammersley and Atkinson, 1995) was followed, during the data analysis we used ANT (Callon, 1986; Latour, 1986; Latour, 1987; Law, 1992) to interpret and make sense of our data. In doing this we avoided the possibility of not having captured important aspects of the phenomenon under investigation that sometimes occurs when a-theoretical inductive methods are used (Sarker and Sidorova, 2006). In line with the sixth principle of interpretive studies (Klein and Myers, 1999), we also were aware of the existence of different interpretations among participants about the same events. We tried to take into account the multiple interpretations of reality expressed by the different actors to achieve a deeper understanding of the project implementation. In alignment to the fourth principle of interpretive research about abstractions and generalization of data through the use of theories (Klein and Myers, 1999), we use ANT as a 'sensitizing device' to view the world in a certain way. It is important to mention here that ANT was adopted in a late stage of this work. While the processes of data collection and initial analysis were conducted under the principles of an inductive approach, ANT was chosen as a suitable theory to make sense of the data and present our findings. To explain possible contradictions between our theoretical preconceptions (e.g. ANT) and the actual findings we constantly reflected on our data and did various cycles of revision of our interpretations (Principle fifth of inductive research in Klein and Myers, 1999). Lastly but not less important we are aware that 'alternative interpretations of data' can be done (Fetterman, 1998).

\section{Case description}

The Human Resources Project Implementation (PI) takes place within the context of the Human Resources Direction at ITESM (Instituto Tecnológico y de Estudios Superiores de Monterrey) which a Multi-campus University System in Mexico. The Multi-campus University System is formed by different campuses across Mexico and has a current enrolment exceeding 90000 students and nearly 20000 employees including service, administrative, teaching and research staff. Studies at the University are officially recognized by the Secretary of Public Education of Mexico (SEP) and by the Southern Association of Colleges and Schools (SACS) of the United States. 
The initiation of the PI can be traced back to four early events (see Section: Antecedents of the project) and was aimed to establish a competency-based approach for developing and managing employees' competencies in four specific areas of the University: libraries, marketing, students' affairs and administrative work, resulting in the modification in the way the current HR practices are performed. Broadly, five different stages take place during the implementation of ModeCo. ${ }^{1}$

First, a definition of a job description is developed to all relevant positions. The job description includes all relevant information of the role under consideration such as the role's objective, expected results and main activities, and the required competencies, knowledge, and experience to appropriately carry out the activities involved in the role. From a catalogue of competencies, employees select certain competencies that need to have as the basis to perform their duties. Second, based on this job description, current and potential employees are evaluated through the application of a series of psychological and psychometrical tests to identify their current competencies' levels and competencies' gaps (At this stage other evaluation techniques are used by the HR staff such as face-to face-interviews, and rolerelated examinations). The gap is identified by a comparison between the employees' current competencies and the previously defined competencies required for each job description. Third, based on the results of the tests (and other inputs from different role-related examinations), a gap between current and desirable competencies is identified and a face-to-face feedback is given to all employees aiming to define a developing plan to narrow the existent gap. Finally, a series of training courses that need to be taken by employees are offered via online in order to improve their current competencies. It is expected that this new way to manage HR will lead to re-define the appraisal compensation system currently used.

In 2006 a new Human Resources President (HRP) for the whole University was hired. Soon after, the PI formally started. Rather than aligning himself with the current HR Practices of that time, the HRP envisioned a new way to manage the Human Resources of the University based on the concept of competencies. To fulfil this goal, immediately after his arrival, he hired a well-reputed HR practitioner who had previously implemented similar projects in the University; he further became the new Human Resources Vice President (HRVP) of the University. Once

\footnotetext{
${ }^{1}$ The Competency-based Model, called ModeCo in this paper, is intellectual property of the University in which this study was conducted. More specific information of ModeCo is not available and has only restricted access, therefore it cannot be published.
} 
they were on charge of the HR Direction, they started to develop a new Competency-based Model (ModeCo) to be used in the context of the University.

At the beginning of the PI, they acknowledged the need to enrol other actors to support the implementation and identified five relevant groups of actors, which would not be necessarily fully enrolled during the PI: 1) Members of the HR Steering Committee who are responsible for the design and deployment of new projects and strategies to all campuses of the University. This HR Steering Committee is formed by the HRP, the HRVP, five Human Resources Vice-Chancellors (HRVCs) representing each of the five geographical zones in Mexico and the Human Resources Directors of the largest campuses, 2) Human Resources Directors (HRDs) who perform the day-to-day HR practices in their own campuses and are responsible for the implementation of new projects and strategies, 3) Vice-Chancellors (VCs) of each campus who are responsible for the overall operation of each campus and have the ability to allocate resources to support new projects (such as the implementation of ModeCo), 4) all employees of the four areas of the University initially involved, who would be those directly receiving the benefits of the project and 5) the Directors of these four areas (DOAs) who would coordinate the implementation in their own Directions.

From the very beginning, it was conceived by the Human Resources President and the Human Resources Vice-President that the implementation would be a slow process that needed to be incorporated into the rhythm of the operational continuity of the University. To facilitate the implementation, they started to communicate and sponsor the Competency-based-Model among all HR staff. Different strategies were deployed by the HRP and the HRVP to gain the support of other relevant actors. Project-related seminars were given via videoconferences by the HRP and HRVP across the different campuses to communicate the aims, benefits and activities of the project; a continuous effort to improve the ModeCo took place along the PI; individual sessions were given in different campuses, where the HRP and the HRVP presented the model to the Vice-Chancellors, the DOAs, and the HRDs of each campus with the aim of persuading them to support the implementation; an online space was created to support collaboration during the implementation; and continuous support to all people involved in the PI was given by the HRVP.

Altogether these strategies positioned the PI in the Human Resources' agenda of the University. 
Despite the fact that ModeCo had been carefully developed and the PI was cautiously planned, the need of reaccrediting studies at the University by an International Association speeded up the PI. The consequences of this situation ultimately shaped the PI, resulting in some problems and causing enormous delays. In mid 2007, when the PI formally began, a taken-for-granted enrolment of different relevant actors was assumed and thus affecting the rhythm of the implementation. During this time, wide-ranging changes to the initial ModeCo occurred, causing misunderstandings among implementers and delays at different stages. In addition during 2008 the economic crash significantly affected the allocation of resources to support the PI. To make it even more difficult, in mid 2009 the HRVP abandoned the University forcing the HRP to readjust responsibilities. To date, the PI is partially implemented, now facing the departure of one of its most relevant promoters.

\section{An interpretation of the human resources project implementation informed by ant}

\section{Before the project implementation}

In ANT, and actor is always a network produced from or as an effect of heterogeneous relations between people and objects (Law, 1992). In our research the whole Multi-campus University system is considered as an actor-network; which first is composed of other actor-networks with aligned interests and second, maintains relationships with other actor-networks such as other universities, the government, controlling bodies for education (SACS), etc. (See Figure 1).

Within the boundaries of the University System actor-network, many interactions take place among different actors. Every campus of the University (each acting as a non-human actor but composed of human and non-human actors) represents an actor-network which at the same time contains other human and non-human actors such as students, employees (e.g. Vice-chancellor, HRDs, administrative staff, teaching staff), HR practices, teaching practices, etc, (See \#1 in Figure 1). Other actors which also exist within the boundaries of the University System are the University Vision; the Research Centres, the Operational Directions of the University such as the Finance, Marketing, IT and Human Resources Directions which exist at the Institutional level of the University, not in every campus (See \#2 in Figure 1). For the purpose of our paper, we show the Human Resources Direction in a separate actor-network in that we aim to show how this actor-network is formed 
by other actor-networks and how their interests are aligned (See \#3 in Figure 1). Being so, the Human Resources Direction can be seen as an actor-network formed by a range of actors whose interests are aligned to those of the University System (See \#4 in Figure 1). Before the PI this actor-network is formed by the previous HR President, the HR Steering Committee and the HRDs of each campus. Moreover, as we aim to show in Figure 1, the HRDs simultaneously belong to two different actor-networks. On the one hand, they have their responsibilities at their own organizational homes where they expend their time, knowledge and resources to perform the HR activities such as hiring, performance appraisal, training, compensation, etc, in a daily basis; in this actor-network (each campus of the University) formal lines of authority go from the VCs to the HRDs. On the other hand, the HRDs also belong to the HR Direction which only exists at the institutional level, but no formal line of authority guides the relationships between the HRP and the HRDs; rather, only when a new HR project or a HR strategic initiative is aimed to be implemented, communication and collaboration take place between these actors (See \#5 in Figure 1). Finally, Figure 1 shows a conflict among two relevant actors in our study: the current HR practices and a specific group of employees: administrative staff (See \#6 in Figure 1). The conflict is the fact that the current HR Practices have been focusing on developing the skills and competencies of certain employees (e.g. teaching staff) but neglecting others (e.g. administrative staff). Other conflicts of different nature may exist between the actors that constitute the University System Actor-Network, but are out of the scope of this paper.

Overall, Figure 1 aims to represent a simplified portrait of the University System actor-network composed of different actor-networks whose interests are supposed to be aligned (see the lines linking the actor-networks to each other) in a certain way that the Vision of the University can be accomplished. (Additional lines can be added between all the actors of each actor-network, showing the alignment of interests. In this figure, these lines have been removed to reduce complexity).

Before the introduction of the PI and although there is a need to improve the HR practices to avoid the under-development of certain groups of employees, the HR Direction can be seen as a stable actor-network which is aligned to the main interest of the University System Actor-Network. The stability of this network would be threatened by four events (presented in the following section) which would result in the transition and therefore the emergence of a new network. In the following section these events are described. 
Figure 1

The multi-campus university system actor-network (before the implementation)

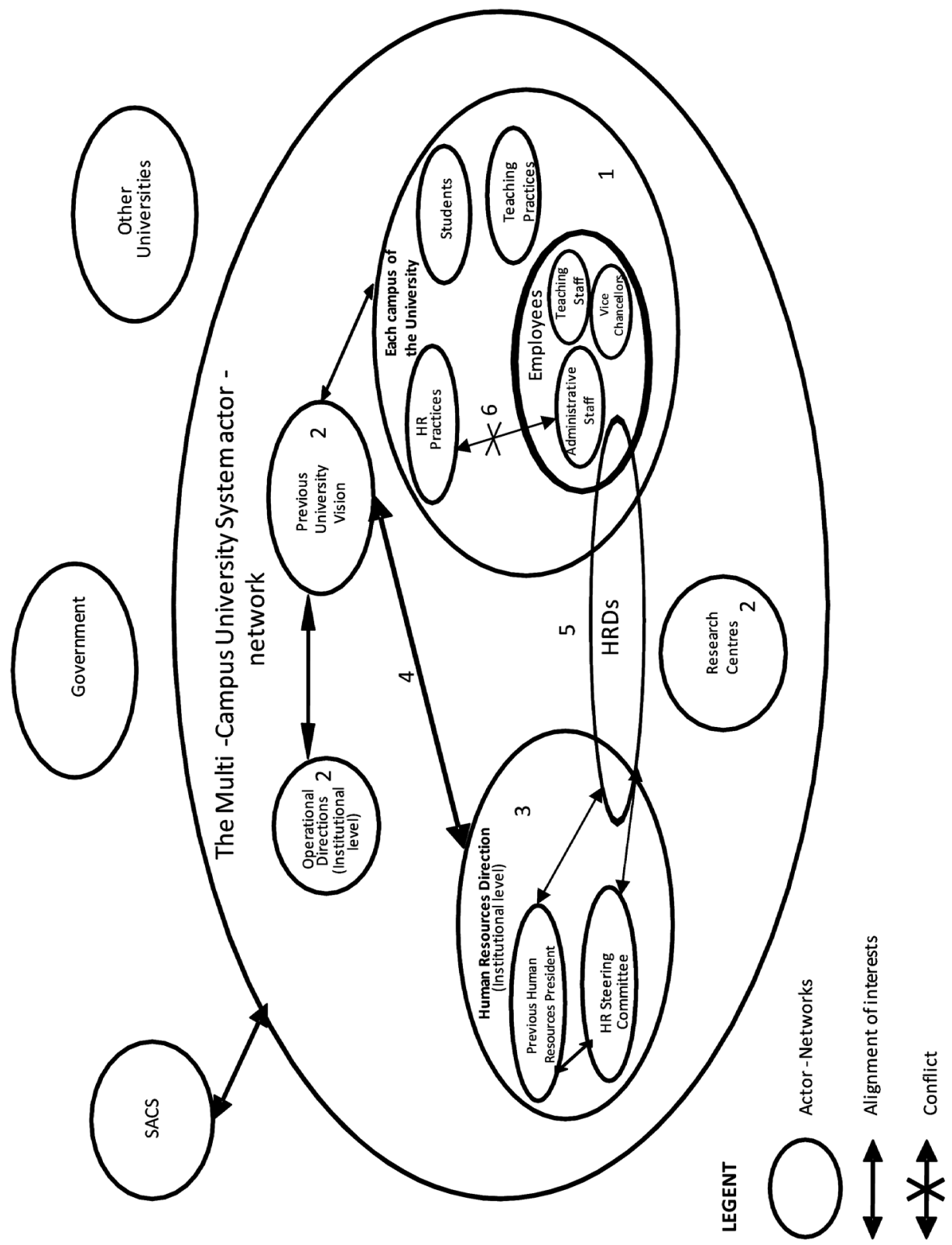




\section{Antecedents of the project implementation}

The initiation of the Human Resources PI can be traced back to four early events: 1) the arrival of a new HR President, 2) a successful inscription resulting from the implementation of a similar Model to ModeCo in five of the University's High Schools, 3) the development of a new Vision of the University, and 4) the need for reaccreditation by SACS to validate studies at the University. Altogether these events would involve different processes of translations, inscriptions and enrolments.

The first event that led to the PI was the retirement of the Human Resources President at that time and the arrival of a new President (HRP). He would be the focal actor leading the PI. To achieve this, the emergence and maintenance of a new network would be required and would strongly depend on his ability to find and enrol allies to support it. Second, the previous success of a similar HR project in the University can be interpreted as an inscription process in which the HRP inscribed his interests in the development of a new model to manage Human Resources.

Once the model developed, it was used as an incentive and helped the HRP to enrol powerful allies such as the Vice-Chancellors (VCs) of the University, who found in this project an attractive opportunity to develop the competencies of their employees in different areas of their campuses. The initial support of the VCs to the PI would be influential enough to increase the network stability of the emerging network. Thirdly, also supporting the PI was another inscription process in which the University redefined its Vision to protect their international recognition as a leading University. By developing the new Vision of the organization, all areas of the University were challenged by the top management and requested to reproblematize the current way of getting things done (e.g. teaching activities, doing research, managing HR, using technology). The HR Direction was not the exception and was also challenged about the way in which they were performing the HR practices. Of special concern to the HR Direction was one of the strategies defined in the new Vision that suggested the need to develop not only employees providing high-standard education and doing high-quality research, but also to develop those involved in supporting (e.g. top management, administrative staff, maintenance staff, etc) the core processes of the University (e.g. teaching, researching and consultancy). A final antecedent leading to the PI was the need for reaccreditation by SACS to validate studies at the University. This reaccreditation requested different operational areas to meet some requirements in order to make their operations transparent. One of those requirements was the need to 
demonstrate the use of job descriptions as a way to identify, develop, evaluate and promote employees in these areas. Coincidentally, the first process taking place in the PI was the development of these job descriptions and therefore different Directors saw in the project an opportunity to meet this requirement by developing their own employees' job descriptions. Altogether, these four events made possible the feasibility of the implementation of ModeCo at an institutional level.

\section{The emerging network}

When the new HRP took his position, he found "[...] a low level of sophistication of the HR practices in which most of the previous work in terms of training and development had focused on the academic staff neglecting the development of other employees in the community of the University [...]" (Interview HRP 1/1402) and envisioned a new paradigm to manage HR. The decision to start the implementation within the four areas previously mentioned, resulted from the neglecting attention given to those areas in the past, and from their need to develop job descriptions as a means for reaccreditation. Rather than aligning himself to the existing network and the HR Practices of that time, the HRP envisioned a new way to manage HR and started to reproblematize the way in which the HR practices were carried out. This situation resulted in the emergence of a new actor-network aiming to introduce the concept of competencies as a complementary way to identify, develop and manage the HR's competencies of certain groups of employees at the University.

The HRP would be the creator of the new network and one of its main representatives. To fulfil his goal, immediately after his arrival, he enrolled a well-reputed HR practitioner who had previously implemented similar projects in the University and became the new Human Resources Vice President (HRVP) of the University. Together, the HRP and the HRVP defined the Project Implementation to be the Obligatory Passage Point (OPP) for the emerging network.

By passing through the OPP, all actors would achieve their own interests: 1) the HRP and the HRVP would integrate all the HR practices based on the concept of competencies (Interview HRP 1/32), 2) the organisational environment at the University would be improved (Interview HRD1 1/161), 3) the HRDs would make

${ }^{2}$ The following format is used along the paper when a citation is taken from one of the interviewees: (Interview, PARTICIPANT, \# of the interview with this participant,/,line in the transcription where the citation is found. Anonymity is kept at all times). 
the selection process of new candidates more clear' (Interview HRD10 1/175), 4) they would easily identify training needs for employees (Interview HRD1 1/153), 5) the performance appraisal process would be more transparent (Interview HRD2 1/356), 6) employees themselves would know if they have the required competencies for their jobs (Interview HRD3 1/212) and therefore they would focused on what they really need in terms of personal development and training (Interview HRD4 1/308), 7) the new practices after implementing ModeCo would help the HR staff to be more organised (Interview HRD1 1/156), 8) ModeCo would achieve its goal of developing a high performing group of employees previously neglected, 9) the areas involved would meet the requirements to be reaccredited by SACS, 10) the HR staff and employees in general would learn and improve their skills and competencies (Interview HRD7 1/363), and 11) the Heads of Departments would be able to communicate their staff what is expected from them (Interview HRD5 1/77). But, on the other hand, in passing through the OPP, actors also would have to deal with some tensions and conflicts associated with this process of translation. HR staff would feel unsecure about how to lead the sessions to develop job descriptions (Interview HRD8 1/278), they would feel the project requires more time that the time they can expend in the project (Interview HRD2 1/233), the HRDs would not be able to solve all their worries and uncertainties regarding the project implementation (Interview HRD7 1/341), they would feel to be ignored by their representatives when making important decision about the PI (Interview HRD8 $1 / 128$ ), and employees would be under stress because they ignore the purpose of new evaluations (Interview HRD7 1/275).

\section{Identification of relevant actors}

Once the OPP was defined, and the emergence of the new network started, the focal actors acknowledged the importance to identify other relevant actors and persuade them to align their interests to those of the ModeCo network, if they wanted their initiative to succeed. Although the HRP and the HRVP assumed the responsibility for identifying and enrolling other key actors; the need to speed up the PI resulted in some omissions to enrol relevant actors and the implementation started solely with the support of the Directors of the four areas initially involved. Not fully enrolled were the HRDs, the HRVCs, the VCs, the employees of the areas concerned and other non-human actors such as ModeCo itself, which was suffering its own transition process; still evolving. Furthermore, other actors such as the current HR practices - posing their own interests, which not necessarily would be aligned to those of the ModeCo network, would be later identified during the PI. 
The stability of the new network would depend on the ability of its focal members to enrol and lock other actors into the right place and by strengthening the relationships between them.

\section{Mobilizing support for the implementation}

To gain the support from other relevant actors, the HRP and the HRVP defined different strategies. They had to negotiate with them and translate their visions to create interessement. While the project implementation started to take place only with the support of the Directors of Areas, the HRP and the HRVP started to negotiate the enrolment of other relevant actors. Far from a straightforward implementation, the PI turned out to be complex, as a consequence of the continuous tensions presented during the interessement and enrolment processes.

One of the first strategies taken by the focal actors was to formalize a Human Resources Steering Committee (referred as the ODC from now on) and to arrange monthly meetings to be attended by its members (The HRP, the HRVP. the HRVCs -representing the HRDs of their geographical regions-, and some HRDs of the largest campuses). During the first meeting, the HRP and the HRVP started to communicate their interest to implement ModeCo at an institutional level and after some time, the concept was inscribed into the everyday language of the ODC members. Together, the creation of the ODC and the recognition of ModeCo as the model to be implemented can be seen as an inscription process which helped the ModeCo network to become more stable. From now on, this network would be formed by the HRP, the HRVP, ModeCo itself, some HRDs and the HRVCs of each geographical zone; altogether would be now responsible for the PI. At this point a full enrolment of all HRDs was assumed but later on, this assumption would be challenged and its consequences would threaten the network stability. While the HRP and the HRVP were integrating the ODC, at the same time, they were working independently with the Directors of the Areas initially involved to implement ModeCo, without directly involving the HRDs of each campus. This situation would threaten the emerging network, as one HRD explains:

There was a direct communication from the Human Resources Steering Committee to the Direction of Marketing and Libraries, they had meetings in which they started to work with job descriptions and suddenly we 'found out' that something was happening. Some employees came to us and asked about competencies and we did not know what had been happening, we were not 
aware. At that time someone complained and they [the HRP and the HRVP] apologized and recognized their mistake. They said: you are right, we made a mistake by not involving Human Resources Directors [of each campus], and indeed it is you [Human Resources Directors of each campus] who should lead the project. Then, they enrolled us into the project (Interview HRD8 1/125).

The failure of the HRP and the HRVP to enrol all HRDs to the ModeCo network was an omission that made some HRDs feel betrayed:

At the beginning, it was a little bit confusing because we did not have all the required information and this situation started to bother some people due to the fact that we were not told about the project implementation. For example they [members of ODC] have said to these four areas that Human Resources of each campus would give support along all the process and we did not know that compromise had been previously arranged... I remember that one campus expressed its worries arguing that it was important to be aware that a compromise had been previously made, not to show us up as a Human Resources area (Interview HRD7 1/92).

As a consequence of this situation and with the aim to solve it, other strategies were defined to enrol all HRDs and other relevant actors. Consequently the HRP and the HRVP visited some campuses as a means to fully enrol HRDs and persuade VCs to allocate resources to support the PI. The HRVP explains:

I used to go to the campuses to meet Vice-chancellors and their heads of departments to sell them the project, to explain them why it is important and to ask them to allocate people, resources and time... I used to do that promotion activity... the first thing [I used to do] was to talk to the Vice-chancellors and their staff, if they bought the idea, we continued, if they did not, we stopped. We did not go to all campuses, not all campuses asked us to go (Interview HRVP 1/284).

Although the HRP and the HRVP visited some campuses to sell the idea to implement ModeCo and support HRDs during the initial phases, the ongoing modifications of ModeCo would also threaten the network stability. Furthermore, the HRP acknowledged that efforts were still needed to persuade VCs to allocate more resources to the PI:

Something that is missing is that we have not been working with the Vicechancellors [VCs] of each campus... I have not had any meeting about this topic with them... so, one problem is that some Vice-chancellors have an idea about 
what we are doing, but for others it is not very clear what we are doing because they have many demands due to their position as Vice-chancellors. Therefore we have an opportunity area that we have to work with; they have to know about this project. They have been informed of all the initiatives, they know, but still something is missing...what is missing is to give them more information [about the project] to make them realize about the benefits it brings (Interview HRP $1 / 262)$.

Another strategy to improve the coordination and deployment of the PI, virtual meetings started to take place between the ODC members and the HRDs. Additionally a series of online seminars were developed and presented to all HR staff responsible for the PI. For the first time (and after two year the PI started), ModeCo was massively presented to all people responsible for the Implementation, including the different stages and activities required to successfully implement ModeCo. It would be available online for future access to all HR staff from the different campuses of the university. Despite the efforts made by the ODC members to fully introduce the ModeCo, in October 2008, the world crises disrupted the PI. Top management' decisions were made to reduce expenses in all the University campuses and therefore the possibility for VCs to allocate more resources was dismissed. In some extreme cases some campuses faced the need to fire some HR staff and other employees. Finally, in July 2009, the HRVP left the University and abandoned the Project. To date, the PI has only partially been implemented, now facing the departure of one of its most relevant promoters.

As Figure 2 shows, the previous Human Resources Direction disappeared (evolved) and instead there is an emerging network -the ModeCo actor-network- (See \#1 in Figure 2) which is aimed to be aligned to the interests of the Multi-Campus University System, declared in the New Vision (See \#2 in Figure 2). This network is mainly represented by the member of the ODC (e.g. the HRP and the HRVCs) and ModeCo (See \#1 in Figure 2); the HRVP does not belong anymore to the ModeCo network (See \#3 in Figure 2). In this new diagram -showing the Multi-Campus University System after the PI- three actor-networks appeared to be in a transition process (See \#4.1, \#4.2, and \#4.3 in Figure 2). First, the ModeCo actor-network which still along the PI was continuously evolving (defining new ways to create job description, improving the evaluation tool to be used, creating new information system to support the evaluation process, etc.) and thus causing sometimes delays and misunderstanding along the implementation. Second, the ODC which was still acquiring its membership (deciding which people would be part of the ODC). 
Figure 2

The multi-campus university system actor-network (during/after the implementation)

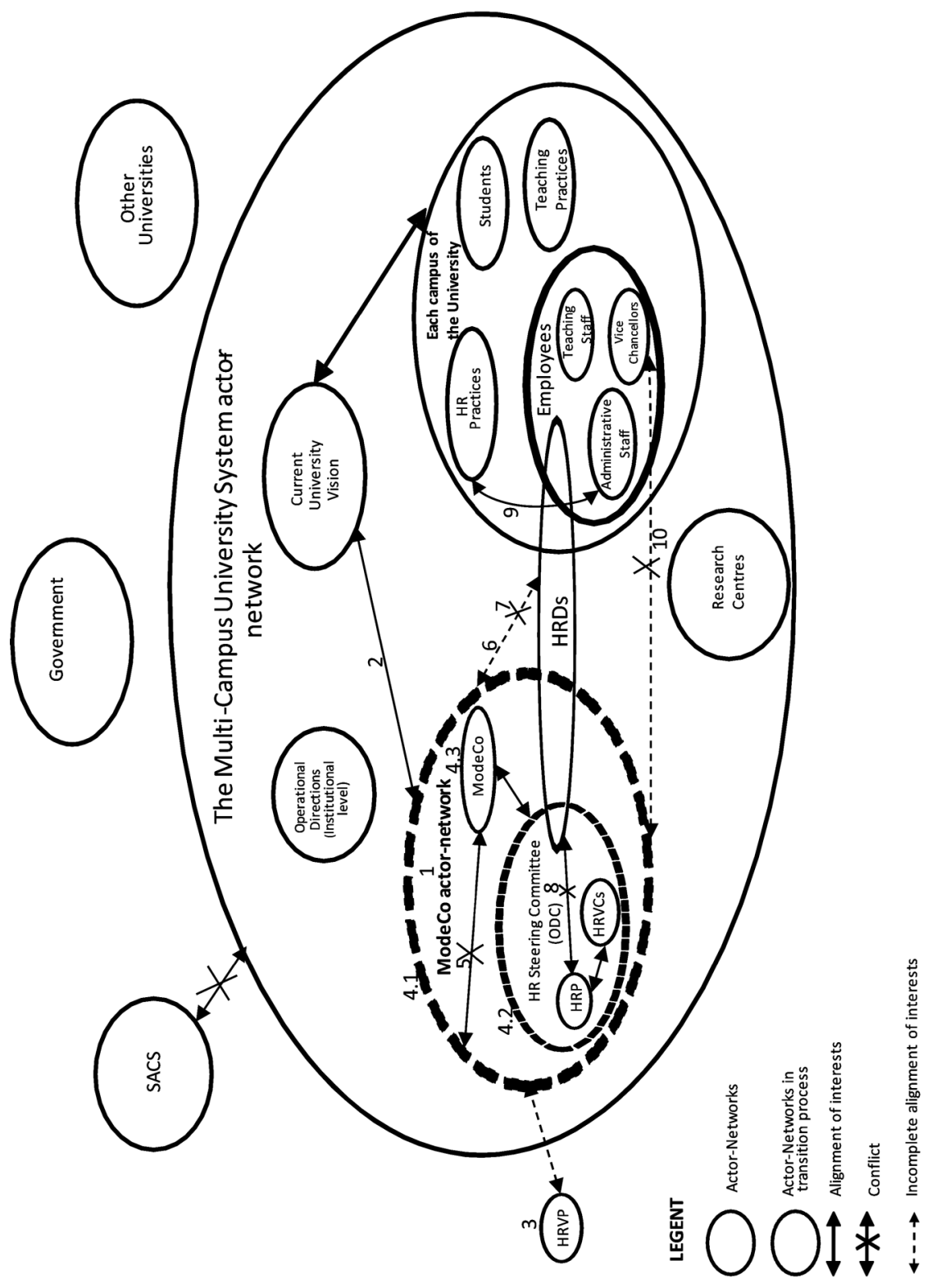


And third, the ModeCo actor-network; together, the retirement of the HRVP, the continuous evolution of ModeCo and the recent creation of the ODC would shape its transition. Furthermore, not all actors within the boundaries of this network have their interests aligned. There is a conflict among ModeCo and the ModeCo network (See \#5 in Figure 2) caused by the transition process in which ModeCo is found. An incomplete alignment of interests is also presented between the HRDs and the ModeCo network (See \#6 in Figure 2). This situation appeared during the emergence of the ModeCo network, when the HRDs were attempted to be enrolled by the HRP to the new network, creating a conflict (See \#7 in Figure 2) expressed in new demands of time and responsibilities for the HRDs, beyond those they already had in their own campuses as part of their day-to-day activities. And finally another conflict occurred among the HRP and the HRDs, when the former failed to enrol HRDs at the very beginning of the PI (See \#8 in Figure 2). Moving from the left ellipse (representing the ModeCo actor-network) to the right one (each campus of the University) other changes occurred. Unlike the previous situation before the PI (See Figure 1) in which a conflict between the HR Practices and the Administrative Staff existed, in Figure 2 this conflict has been removed as a consequence of the initiative taken by the HRP (and the ModeCo network) to develop the competencies of employees previously neglected, instead the arrow among these two actors shows an alignment of interests (See \#9 in Figure 2). Finally, this Figure also shows another conflict that took place during the PI; one created as a consequence of the world crisis that forced the VCs of each campus to reduce the allocation of resources to support the PI (See \#10 in Figure 2).

\section{Discussion}

At the beginning of this paper two main objectives were proposed. In the previous section, ANT was used to inform the Implementation of a Human Resources Project in a Multi-campus University System and thus allow us to achieve the first goal of the paper. Additionally by describing the PI in terms of ANT relevant aspects of the PI were described. In this section we focus our attention on the aspects that emerged from the previous analysis; that is, to shed some initial insights to understand the issues (positive and negative) that shaped the rhythm of this implementation. We present a table in which a series of overlapping events are categorized into four different groups (according to the stage of the PI in which they occurred); this categorization is influenced by the work of Sarker and Sidorova (2006) but goes beyond it, in that ours focuses on both the strengths and weaknesses of the focal actors when implementing 


\section{ModeCo, not only on the errors and omissions made, as Sarker and Sidorova (2006) proposed.}

Table 3

Issues that shaped the rhythm of the project implementation

\begin{tabular}{|c|c|c|c|}
\hline Stage & & $\begin{array}{l}\text { Concept suggested by } \\
\text { ANT }\end{array}$ & Example based on the case study \\
\hline $\begin{array}{l}\text { During } \\
\text { Problematization }\end{array}$ & Strength & $\begin{array}{l}\text { The emergence of a new } \\
\text { focal actor }\end{array}$ & $\begin{array}{l}\text { Hiring of a new Human Resources } \\
\text { President (HRP) who brought with him the } \\
\text { idea of a new paradigm to manage Human } \\
\text { Resources at the University. This event } \\
\text { led to the creation of the ModeCo actor- } \\
\text { network }\end{array}$ \\
\hline $\begin{array}{l}\text { During } \\
\text { Problematization }\end{array}$ & Strength & $\begin{array}{l}\text { Identification of other } \\
\text { relevant actors }\end{array}$ & $\begin{array}{l}\text { When the new HRP arrived he immediately } \\
\text { detected an expert on HR and invited him } \\
\text { to participate in the Project Implementation. } \\
\text { This person would become the HRVP and } \\
\text { would lead the PI. }\end{array}$ \\
\hline $\begin{array}{l}\text { During } \\
\text { Problematization/ } \\
\text { Interessement }\end{array}$ & Strength & $\begin{array}{l}\text { Creation of inscriptions/ } \\
\text { strategies to enrol new } \\
\text { actors }\end{array}$ & $\begin{array}{l}\text { Once the HRP and the HRVP took their } \\
\text { responsibilities, they started to formalize } \\
\text { the creation of a Human Resources Steering } \\
\text { Committee which would be responsible for } \\
\text { the design and deployment of the PI in all } \\
\text { campuses of the University. }\end{array}$ \\
\hline $\begin{array}{l}\text { During } \\
\text { Problematization }\end{array}$ & Strength & Inscription process & $\begin{array}{l}\text { The creation of a new Vision of the } \\
\text { University requiring the improvement of all } \\
\text { practices within the University motivated } \\
\text { and allowed the new HRP to promote } \\
\text { and highlight the need of a new Human } \\
\text { Resources Model to be followed. }\end{array}$ \\
\hline $\begin{array}{l}\text { During } \\
\text { Problematization/ } \\
\text { Interessement }\end{array}$ & Strength & $\begin{array}{l}\text { Strategies to enrol new } \\
\text { actors. Sponsoring the } \\
\text { emerging network }\end{array}$ & $\begin{array}{l}\text { When the HRP and the HRVP defined the } \\
\text { Project Implementation to be the Obligatory } \\
\text { Passage Point (OPP) for the emerging } \\
\text { network, the general perception of other } \\
\text { relevant actors was positive. These other } \\
\text { actors realised that by passing through the } \\
\text { OPP, they would achieve their own interests } \\
\text { such as meeting the requirements demanded } \\
\text { for reaccreditation, identifying training } \\
\text { needs for their employees, developing their } \\
\text { employees' competencies, etc. }\end{array}$ \\
\hline
\end{tabular}




\begin{tabular}{|c|c|c|c|}
\hline \multicolumn{2}{|l|}{ Stage } & $\begin{array}{l}\text { Concept suggested by } \\
\text { ANT }\end{array}$ & Example based on the case study \\
\hline $\begin{array}{l}\text { During } \\
\text { Problematization/ } \\
\text { Interessement/ } \\
\text { Enrolment }\end{array}$ & Weakness & $\begin{array}{l}\text { Failure to recognize the } \\
\text { significance of relevant } \\
\text { actors }\end{array}$ & $\begin{array}{l}\text { Although the HRP and the HRVP identified } \\
\text { five relevant groups of actors, they failed to } \\
\text { fully recognize the importance of a number } \\
\text { of human/nonhuman actors that had the } \\
\text { potential to influence the outcome of the } \\
\text { implementation. Primarily importance } \\
\text { was given to human actors. ModeCo as a } \\
\text { nonhuman actor was not initially given the } \\
\text { importance it deserved as an influential } \\
\text { actor. }\end{array}$ \\
\hline
\end{tabular}

$\begin{array}{lll}\begin{array}{l}\text { During } \\ \text { Interessement/ }\end{array} & \begin{array}{l}\text { Creation of inscriptions/ } \\ \text { Enrolment }\end{array} & \begin{array}{l}\text { strategies to enrol new } \\ \text { actors }\end{array}\end{array}$

During Enrolment
Once the HRP and the HRVP conceived the idea of ModeCo, they created a series of project-related seminars to communicate and sponsor the Competency-based-Model among all HR staff.

\begin{tabular}{|c|c|c|c|}
\hline $\begin{array}{l}\text { During } \\
\text { Interessement/ } \\
\text { Enrolment }\end{array}$ & Weakness & $\begin{array}{l}\text { Taken-for-granted } \\
\text { enrolment of different } \\
\text { relevant actors }\end{array}$ & $\begin{array}{l}\text { By speeding up the Project Implementation, } \\
\text { as a consequence of the need for } \\
\text { reaccreditation, a taken-for-granted } \\
\text { enrolment of different relevant actors was } \\
\text { assumed by the HRP and the HRVP. This } \\
\text { situation would slow down the PI. }\end{array}$ \\
\hline $\begin{array}{l}\text { During } \\
\text { Interessement/ } \\
\text { Enrolment }\end{array}$ & Weakness & Parallel transition & $\begin{array}{l}\text { In } 2007 \text { when the PI started, ModeCo was } \\
\text { still evolving and thus in its own transition. } \\
\text { These simultaneous transitions (those of } \\
\text { ModeCo and the ModeCo actor-network) } \\
\text { resulted in wide-ranging changes to the initial } \\
\text { model, and thus causing misunderstandings } \\
\text { and delays along the implementation. }\end{array}$ \\
\hline $\begin{array}{l}\text { During } \\
\text { Interessement/ } \\
\text { Enrolment }\end{array}$ & Weakness & $\begin{array}{l}\text { Pressure from other actor } \\
\text { networks }\end{array}$ & $\begin{array}{l}\text { Before ModeCo was fully developed, the } \\
\text { need for reaccreditation by SACS to validate } \\
\text { studies at the University forced the launching } \\
\text { of the PI. This resulted in a PI launching } \\
\text { before it was initially planned. }\end{array}$ \\
\hline $\begin{array}{l}\text { During } \\
\text { Interessement/ } \\
\text { Enrolment }\end{array}$ & Strength & $\begin{array}{l}\text { Strategies to enrol new } \\
\text { actors }\end{array}$ & $\begin{array}{l}\text { The HRP and the HRVP visited different } \\
\text { campuses where they introduced the } \\
\text { model to the Vice-Chancellors, the DOAs, } \\
\text { and the HRDs of each campus with the } \\
\text { aim of persuading them to support the } \\
\text { implementation. }\end{array}$ \\
\hline $\begin{array}{l}\text { During } \\
\text { Interessement/ } \\
\text { Enrolment }\end{array}$ & Strength & $\begin{array}{l}\text { Strategies to enrol new } \\
\text { actors }\end{array}$ & $\begin{array}{l}\text { The creation of an online community to } \\
\text { promote and support collaboration during } \\
\text { the implementation among all people } \\
\text { involved in the Implementation. }\end{array}$ \\
\hline
\end{tabular}




\begin{tabular}{|c|c|c|c|}
\hline Stage & & $\begin{array}{l}\text { Concept suggested by } \\
\text { ANT }\end{array}$ & Example based on the case study \\
\hline $\begin{array}{l}\text { During } \\
\text { Interessement/ } \\
\text { Enrolment }\end{array}$ & Weakness & Betrayal & $\begin{array}{l}\text { Some HRDs felt to be ignored by their } \\
\text { representatives (the HRP and the HRVP) } \\
\text { when making important decision about the } \\
\text { PI. Before the HRDs were invited to take } \\
\text { part in the project, the HRP and the HRVP } \\
\text { had been working with the Directors of } \\
\text { Areas initially involved without previous } \\
\text { notification to the HRDs. }\end{array}$ \\
\hline $\begin{array}{l}\text { During } \\
\text { Interessement/ } \\
\text { Enrolment }\end{array}$ & Weakness & $\begin{array}{l}\text { Taken-for-granted } \\
\text { enrolment of different } \\
\text { relevant actors }\end{array}$ & $\begin{array}{l}\text { Some employees of the University were } \\
\text { under stress because they were not aware of } \\
\text { the purpose of some evaluations they had to } \\
\text { take part in when the PI started. Just after } \\
\text { some time they were informed about the } \\
\text { aims of these evaluations. }\end{array}$ \\
\hline $\begin{array}{l}\text { During } \\
\text { Enrolment/ Post- } \\
\text { enrolment }\end{array}$ & Weakness & $\begin{array}{l}\text { External event to the } \\
\text { actor-network under } \\
\text { study }\end{array}$ & $\begin{array}{l}\text { During } 2008 \text { the economic crash significantly } \\
\text { affected the allocation of resources to } \\
\text { support the PI. In some extreme cases some } \\
\text { HR staff had to be fired as a means for } \\
\text { saving resources. }\end{array}$ \\
\hline $\begin{array}{l}\text { During Post- } \\
\text { enrolment }\end{array}$ & Weakness & Process of betrayal & $\begin{array}{l}\text { In mid } 2009 \text { the HRVP abandoned the } \\
\text { University forcing the HRP to readjust } \\
\text { responsibilities. Before his departure } \\
\text { he was the main actor in charge of the } \\
\text { Implementation. }\end{array}$ \\
\hline $\begin{array}{l}\text { Along all } \\
\text { the Project } \\
\text { Implementation }\end{array}$ & Weakness & $\begin{array}{l}\text { Development of multiple } \\
\text { memberships in different } \\
\text { actor networks }\end{array}$ & $\begin{array}{l}\text { When the HRDswere attempted to be enrolled } \\
\text { into the PI, which promotes organizational } \\
\text { change, they were already involved in the } \\
\text { HR Practices that had to perform as part } \\
\text { of their day-to-day responsibilities in their } \\
\text { own organizational homes (activities such } \\
\text { as recruitment, training and development, } \\
\text { personnel administration, compensation, and } \\
\text { labour relations). These HR Practices help to } \\
\text { maintain the organizational continuity of the } \\
\text { campuses. As a consequence of this situation } \\
\text { they developed multiple memberships and } \\
\text { began to face multiple demands coming from } \\
\text { both their own campuses and the emerging } \\
\text { Actor-Network; finally this situation would } \\
\text { result in a partial enrolment of the HRDs } \\
\text { into the ModeCo network. }\end{array}$ \\
\hline
\end{tabular}




\section{Conclusions}

We have observed that the PI is a process whereby a core group of actors shapes the formation of an actor-network and attempted to persuade other actors to align their interests to the requirements of an emerging network. As shown in Table 3 in the discussion section, a series of events that occurred along the different stages of the PI shaped this process, some of them weakening and others strengthening the stability of the emerging network. Those that negatively affected the implementation are: 1) failure to recognize the significance of relevant actors, 2) taken-for-granted enrolment of different relevant actors, 3) parallel transition, 4) pressure from other actor networks, 5) processes of betrayal, 6) external events to the emerging actornetwork, and 7) development of multiple memberships by some relevant actors in different actor-networks with conflicting demands. Other events/elements such as 1) the emergence of a new focal actor, 2) the identification of other relevant actors by the focal actor, 3) the creation of inscriptions to protect some interests, 4) new inscription processes, 5) the development of different strategies to enrol new actors and 6) the sponsorship of the emerging network by the focal actors increased the network stability and thus supported the PI.

Furthermore, using an ANT approach to analyze a project implementation provides a better understanding of the complexities associated with this process. The following statements are a number of situations that capture how ANT was useful in our study: 1) to identify all relevant actors, including those with a non-human nature such as the HR Competency-Based Model (ModeCo) and the current Human Resource Work Practices in which HR staff are involved; 2) to explain a network formation as a process to persuade others to realign their interests to those of the emerging network; 3 ) to understand how the relevance of actors varies across the different processes of translation and be able to focus our attention in actors located at different level of the organisation; 4) to identify and explain how the actors involved took different strategies to align the interests of new actors into their own network; 5) to explain how artefacts are created through processes of inscription in order to protect certain interests; 6) to explain processes of betrayal in which actors do not abide to previous agreements made with their representatives; 7) to explain sources of conflict between actors that result in either process of betrayal or process of interests' alignment; 8) to explain how human actors confer power to non-human actors; and 9) to explain how different networks of aligned interests compete for the enrolment of actors. 


\section{Acknowledgements}

One of the authors would like to thank CONACYT-MEXICO (Consejo Nacional de Ciencia y Tecnología) and SEP-MEXICO (Secretaría de Educación Pública) for funding part of this research. Also we acknowledge the support received from all participants in the project, specially, we are very grateful to the Vice President and President of Human Resources of the University where we conducted our study for giving us access and support along our research.

\section{References}

Blackburn, S. (2002). The project manager and the project-network. International Journal of Project Management 20 (3): 199-204.

Callon, M. (1986). Some elements of a sociology of translation; domestication of the scallops and the fishermen of St Brieuc Bay. In: Law, J. (ed.), Power, action and nelief a new sociology of knowledge? London: Routledge and Kegan Paul.

\& B. Latour (1981). Unscrewing the big Leviathan: how actors macrostructure reality and how sociologists help them to do so. In: Knorr-Cetina, K.D. \& A.V. Cocourel (eds.), Advances in social theory and methodology: toward an integration of micro and macro-sociologies. London: Routledge and Kegan Paul: 277-303.

Cho, S., L. Mathiassen \& A. Nilsson (2008). Contextual dynamics during health information systems implementation: an event-based actor-network approach. European Journal of Information Systems 17 (6): 614-630.

Dinsmore, P.C., T.J.Cooke-Davies \& T. Cooke-Davies (2005). The right projects done right!: from business strategy to successful project implementation. San Francisco: John Wiley and Sons.

Eisenhardt, K.M. (1989). Building theories from case study research. Academy of management review 14 (2): 532-550. 
Fetterman, L. (1998). Ethnography. In: Bickman, L. \& D.J. Rog (eds.), Handbook of applied social research methods. Thousand Oaks, California: Sage Publications Inc.

Finney, S. \& M. Corbett (2007). ERP implementation: a compilation and analysis of critical success factors. Business Process Management Journal 13 (3): 329-347.

Hammersley, M. \& P. Atkinson (1995). Ethnography: principles in practice. London: Routledge.

Huy, Q.N. (2002). Emotional balancing of organizational continuity and radical change: the contribution of middle managers. Administrative science quarterly 47 (1): 31-69.

Klein, H.K. \& M.D.Myers (1999). A set of principles for conducting and evaluating interpretive field studies in information systems. Mis Quarterly 23 (1): 67-93.

Kuruppuarachchi, P.R., P. Mandal \& R. Smith (2002). IT project implementation strategies for effective changes: a critical review. Logistics information management 15 (2): 126-137.

Latour, B. (1986). The powers of association. In: Law, J. (ed.), Power, action and belief a new sociology of knowledge? London: Routledge and Kegan Paul.

(1987). Science in action: how to follow scientists and engineers through society. Cambridge: Harvard University Press.

Law, J. (1992). Notes on the theory of the actor-network: ordering, strategy, and heterogeneity. Systems Practice 5 (4): 379-393.

Linde, A., H. Linderoth \& C. Raisanen (2003). An actor network theory perspective on IT-projects: a battle of wills. Action in language, organizations and information systems 2003, Linkoping University.

Martinez, E.V. (1994). Avoiding large-scale information systems project failure: the importance of fundamentals. Project Management Journal 25 (2): 17-25. 
Monteiro, E. (2004). Actor network theory and cultural aspects of interpretative studies. In: Avgerou, C., C. Ciborra \& F. Land (eds.), The social study of information and communication technology: innovation, actors and contexts. Oxford: 129-139

Pinto, J. \& D. Slevin (1986). The project implementation profile: new tool for project managers. Project Management Journal 17 (4): 57-63.

Robey, D. (1996). Research commentary: diversity in information systems research: threat, promise, and responsibility. Information Systems Research 7 (4): 400-408.

Sarker, S. \& A. Sidorova (2006). Understanding business process change failure: an actor-network perspective. Journal of Management Information Systems 23 (1): 51-86.

Schultz, R.L., D.P. Slevin \& J.K. Pinto (1987). Strategy and tactics in a process model of project implementation. Interfaces 17 (3): 34-46.

Tatnall, A. \& S. Burgess (2002). Using actor-network theory to research the implementation of a BB portal for regional SMEs in Melbourne, Australia. 15th Bled Electronic Commerce Conference eReality: Constructing the eEconomy. Citeseer: 179-189.

\& A. Gilding (1999). Actor-network theory and information systems research. Australian Conference on Information Systems 1999. Citeseer: 955-966.

Van House, N.A. (2003). Science and technoloav studies and information studies. Annual Review of Information Science and Technology V (38): 3-86. Information Today, Inc.

Walsham, G. (1995). Interpretive case studies in IS research: nature and method. European Journal of Information Systems 4 (2): 74-81.

Walsham, G. (1997). Actor-network theory and IS research: current status and future prospects. In: Lee, A., J. Liebenau \& J. DeGross (eds.), Information Systems and Qualitative Research. London: Chapman and Hall: 466-480. 
(2006). Doing interpretive research. European Journal of Information Systems 15: 320-330.

Zhang, L., M.K.O. Lee, Z. Zhang \& P. Banerjee (2003). Critical success factors of enterprise resource planning systems implementation success in China. 36th Hawaii International on System Sciences 3. Citeseer. 
